\title{
Growth, photosynthesis and stress indicators in young rosewood plants (Aniba rosaeodora Ducke) under different light intensities
}

\author{
José Francisco de Carvalho Gonçalves ${ }^{1 *}$, Denize Caranhas de Sousa Barreto', Ulysses Moreira dos Santos \\ Junior $^{1}$, Andreia Varmes Fernandes ${ }^{1}$, Paulo de Tarso Barbosa Sampaio ${ }^{1}$ and Marcos Silveira Buckeridge ${ }^{2}$
}

${ }^{1}$ Laboratório de Fisiologia e Bioquímica Vegetal, Instituto Nacional de Pesquisas da Amazônia, CP 478, 69011-970, Manaus, AM, Brasil; ${ }^{2}$ Seção de Fisiologia e Bioquímica de Plantas, Instituto de Botânica, CP 4005, 01061-970, São Paulo, SP, Brazil; *Corresponding author: jfc@inpa.gov.br.

Received: 03/08/2005, Accepted: 03/10/2005

Aniba rosaeodora is an Amazonian tree species that belongs to the family Lauraceae. Due to intense exploitation for extraction of essential oils (mainly linalol), A. rosaeodora is now considered an endangered species. On the other hand, there is little information about its ecophysiology which would be useful to support future forest planting programs. Hence, the effect of different light intensities on the growth and photosynthetic characteristics of young plants of $A$. rosaeodora was studied. Ninemonth-old plants were subjected to four light treatments $\left(\mathrm{T}_{1}=10 \mathrm{a} 250 \mu \mathrm{mol} \cdot \mathrm{m}^{-2} \cdot \mathrm{s}^{-1} / \mathrm{control} ; \mathrm{T}_{2}=500\right.$ to $800, \mathrm{~T}_{3}=700$ to 1000 and $\mathrm{T}_{4}=1300$ to $1800 \mu \mathrm{mol} . \mathrm{m}^{-2} \cdot \mathrm{s}^{-1}$ / full sunlight). Allometric variables, gas exchange, contents of pigments and chlorophyll $a$ fluorescence were analysed. As to the relative growth rates, it was found that plants of $A$. rosaeodora showed higher biomass accumulation when grown under intermediary irradiance conditions $\left(\mathrm{T}_{2}\right)$. The best photosynthetic performance was achieved under conditions of $\mathrm{T}_{3}$. When growth was correlated with photosynthesis, it was found that plants under treatments $\mathrm{T}_{2}$ and $\mathrm{T}_{3}$ presented better responses in comparison with the lowest $\left(\mathrm{T}_{1}\right)$ and highest $\left(\mathrm{T}_{4}\right)$ light extremes. The highest pigment contents were obtained for plants in the shade $\left(\mathrm{T}_{1}\right)$ and the lowest for those exposed to full sunlight $\left(\mathrm{T}_{4}\right)$. The photochemical efficiency of photosystem II $\left(F_{v} / F_{m}\right)$ was found that only plants in the shade treatment $\left(\mathrm{T}_{1}\right)$ presented no stress from high irradiance. These findings suggest that both treatments $\left(\mathrm{T}_{1}\right.$ and $\left.\mathrm{T}_{4}\right)$ altered the function of the $A$. rosaeodora plants, inhibiting photosynthesis and growth. Plants of A. rosaeodora developed photo-protection mechanisms under full sunlight. However, the species presented better photosynthetic response and biomass gain under intermediary irradiance conditions, displaying relative physiological plasticity, during the seedling phase.

Key words: chlorophyll $a$ fluorescence, chloroplast pigment contents, gas exchanges, photochemical efficiency of photosystem II, relative growth rate, tropical species.

Crescimento, fotossíntese e indicadores de estresse em plantas jovens de pau-rosa (Aniba rosaeodora Ducke) sob diferentes intensidades luminosas: Essa espécie arbórea da Amazônia, Aniba rosaeodora Ducke, pertence à família das Lauraceae. Em vista da intensa e desordenada exploração, visando à extração de óleos essenciais (linalol), o pau-rosa figura na lista de espécies ameaçadas de extinção. Poucos estudos ecofisiológicos têm sido feito no sentido de subsidiar futuros programas de plantios florestais. Dessa forma, pesquisou-se o efeito de diferentes irradiâncias sobre as características fotossintéticas e de crescimento em plantas de $A$. rosaeodora, na fase juvenil. Plantas com nove meses foram submetidas a quatro tratamentos de luz $\left(\mathrm{T}_{1}=\right.$ $10 \mathrm{a} 250 \mu \mathrm{mol} . \mathrm{m}^{-2} \cdot \mathrm{s}^{-1} /$ controle; $\mathrm{T}_{2}=500$ a $800, \mathrm{~T}_{3}=700 \mathrm{a} 1.000 \mathrm{e} \mathrm{T}_{4}=1.300 \mathrm{a} 1.800 \mu \mathrm{mol} \cdot \mathrm{m}^{-2} \cdot \mathrm{s}^{-1} /$ pleno sol). Analisaramse variáveis alométricas, trocas gasosas, teores de pigmentos cloroplastídicos e a fluorescência da clorofila $a$. Quanto ao crescimento relativo, observou-se que plantas de A. rosaeodora exibiram maior acúmulo de biomassa quando crescidas sob condições intermediárias de irradiância $\left(\mathrm{T}_{2}\right)$. O melhor desempenho fotossintético foi induzido por $\mathrm{T}_{3}$. Quando se correlacionou crescimento com fotossíntese, percebeu-se que as plantas submetidas aos tratamentos $\mathrm{T}_{2}$ e $\mathrm{T}_{3}$ exibiram melhores respostas em comparação com os extremos de menor $\left(\mathrm{T}_{1}\right)$ e maior irradiâncias $\left(\mathrm{T}_{4}\right)$. Os maiores teores de pigmentos cloroplastídicos foram 
obtidos nas plantas sob sombra $\left(\mathrm{T}_{1}\right)$ e os menores teores encontrados naquelas expostas a pleno sol $\left(\mathrm{T}_{4}\right)$. Quanto à eficiência fotoquímica do fotossistema II $\left(F_{v} / F_{m}\right)$ observou-se que apenas as plantas do tratamento de sombra $\left(\mathrm{T}_{1}\right)$ não apresentaram estresse por alta irradiância. Os resultados sugerem que ambos os tratamentos $\left(\mathrm{T}_{1} \mathrm{e}_{4}\right)$ alteraram a funcionalidade das plantas de A. rosaeodora, inibindo a fotossíntese e o crescimento. A pleno sol, plantas de A. rosaeodora desenvolveram mecanismos de fotoproteção. No entanto, a espécie apresentou melhor resposta fotossintética e ganho de biomassa em condições intermediárias de irradiância, demonstrando relativa plasticidade fisiológica, durante o estádio juvenil.

Palavras-chave: eficiência fotoquímica do fotossistema II, espécies tropicais, fluorescência da clorofila $a$, pigmentos cloroplastídicos, taxa de crescimento relativo, trocas gasosas.

\section{INTRODUCTION}

The Amazon forest has suffered greatly due to the impacts of human activity (burning, deforestation and mining) and natural disturbances ("el niño" and "la niña", "blowdown" and tree falling). With regard to deforestation, recent estimates revealed that between 2001 and 2003 some $67,250 \mathrm{~km}^{2}$ of Brazilian Amazonian forest have been cleared (INPE, 2004). One of the consequences is the decline of tree populations, especially of plant species that are used to produce extracts of commercial value. One example is rosewood (Aniba rosaeodora Ducke), a species of the family Lauraceae which is widely distributed throughout the tropical and subtropical regions of the planet (Werff and Richter, 1996). For decades, A. rosaeodora has been exploited for extraction of linalol, a product used in perfumes (Alencar and Fernandes, 1978). As a result, it is now believed that rosewood faces a serious risk of extinction (Rosa et al., 1997; May and Barata, 2004). Evidence of this decrease in the Amazonian populations of rosewood is the recent data of a reduction in the volume of linalol exported by the Amazonas state. In 1995 this state exported about 41 tons of linalol, whereas in 2000 the total volume produced decreased to 4 tons (Sampaio et al., 2003). One way to avoid the loss of populations of rosewood would be to prevent uncontrolled exploitation and at the same time to implement programs of reintroduction of this species in the ecosystem. However, the second measure is limited by the lack of information regarding the ecophysiology and forestry management of $A$. rosaeodora. These have been considered limiting factors in the implementation of large-scale plantation programs in the areas of extraction and natural management of the species. In this context, for rosewood plantations to be successful, it will be necessary to obtain more information about its ecophysiological strategies.

Among the main environmental factors, light is perhaps the most influential factor involved in the survival, growth and reproduction of tropical species. Light responses usually provoke physiological alterations, which are determinant for $\mathrm{CO}_{2}$ assimilation and optimization of gas exchange (Sands, 1995). Light can also influence other physiological processes, both quantitatively and qualitatively. For this reason, environments that are either shaded or under full sunlight can inhibit the photosynthetic process, simply because there is too little or too much light (Zhang et al., 2003).

Indeed, it has been shown that the excess of light can affect plant growth and as a consequence provoke a reduction of field productivity as a result of photoinhibition (Kitao et al., 2000; Gonçalves et al., 2001; Marenco et al., 2001; Kull 2002). The different light intensities promote changes in both the physiology and morphology of the plants, which are features that result from the interaction between gene expression and the environment (Moraes Neto and Gonçalves, 2001). Normally, the measurement of the pigments from chloroplasts and the analysis of the fluorescence of chlorophyll $a$ are used as stress indicators of high irradiance in the plants (Hendry and Prince, 1993; Stancato et al., 2001). The synthesis and/or degradation of chlorophyll occur naturally with the presence of light. Nonetheless, the excess of light can cause greater degradation and consequently, a reduction in the levels of total chlorophyll (Engel and Poggiani, 1991). In environments with high irradiance, the increase of photooxidation of chlorophyll depends upon the concentration of carotenoids, which can prevent photoxidative action (Bartley and Scolnik, 1995). Additionally, the excess of irradiance can contribute to the decrease of photosynthetic capacity which in turn contributes to the occurrence of photoinhibition (Kitao et al., 2000). Photoinhibition is triggered by inactivation of the photochemical reaction centre in photosystem II, probably as a result of damage suffered by the D1 protein (Krause et al., 1999) which under conditions of high irradiance can become inactivated or even undergo irreparable degradation, thus jeopardizing the photosynthetic mechanism (Baker and Bowyer, 1994). 
An efficient photosynthetic activity is necessary for high production of plant biomass. Nevertheless, abiotic factors (light, water, $\mathrm{CO}_{2}$ and nutrients) and physiologically controlled factors (stomatic conductance, transpiration) can strongly influence this activity. In the present study, we followed growth, gas exchange, pigment concentrations and photochemical efficiency of photosystem II in young plants of A. rosaeodora subjected to increasing levels of irradiance.

\section{MATERIAL AND METHODS}

Study area and experiment installation: The study was conducted under nylon tarpaulins at the National Institute of Amazonian Research in the V-8 campus in Manaus, Amazonas, Brazil. According to Koppen's climatic classification, the climate of this region is of the $A f i$ type with an average annual precipitation of $2200 \mathrm{~mm}$ and average temperature of $27 \pm 5{ }^{\circ} \mathrm{C}$. The experiment was installed using 9-month-old rosewood (Aniba rosaeodora Ducke) plants produced from seeds collected from Adolpho Ducke Forest Reservation, located at Km 25 of the AM-10 highway (Manaus-Itacoatiara). Healthy seeds were selected following a model of uniformity in size. After soaking in $1 \%(\mathrm{v} / \mathrm{v})$ sodium hypochlorite solution for $10 \mathrm{~min}$ and thoroughly washed with tap water. The seeds were then placed in plastic boxes containing washed sand for germination. Once the plants reached $10 \mathrm{~cm}$ in height, they were transplanted to black polyethylene bags containing $5 \mathrm{~kg}$ of compost mixture and sand $(2: 1, \mathrm{w} / \mathrm{w})$, where they remained for 25 days for an acclimation period. Plants were then subjected to 4 different levels of light intensities: $T_{1}=10$ to 250 for control treatment, under plant cover; $\mathrm{T}_{2}=500$ to 800 obtained with nylon cover; $\mathrm{T}_{3}=700$ to 1000 obtained with nylon cover; $\mathrm{T}_{4}=1300$ to 1800 $\mu$ mol. $\mathrm{m}^{-2} \cdot \mathrm{s}^{-1}$ obtained by leaving plants under direct sunlight. During the experiment, plants were watered daily.

Growth analysis: The growth of the rosewood plants was evaluated by allometric readings and mass determination. The relative growth rates of different plant parts such as leaves, stem and roots were obtained while measurements were made at the beginning and end of the experiment. The measurements were taken at the beginning and end of a six month period (180 days). Upon completion of the experiment, leaves, stems and roots were separated and oven-dried at $70^{\circ} \mathrm{C}$ until the dry material reached constant mass. The determination of the relative growth rate of the leaf (RGR-L), stem (RGR-S), root (RGR-R) and total (RGR-
Total) biomass was achieved using the equations below according to the methodology described by Bugbee (1996) and Davanso et al. (2002):

$$
\begin{aligned}
& \text { RGR-L }=\left(\log \mathrm{L}_{2}-\log \mathrm{L}_{1}\right) /\left(\mathrm{t}_{2}-\mathrm{t}_{1}\right) \\
& \text { RGR-S }=\left(\log \mathrm{S}_{2}-\log \mathrm{S}_{1}\right) /\left(\mathrm{t}_{2}-\mathrm{t}_{1}\right) \\
& \text { RGR-R }=\left(\log \mathrm{R}_{2}-\log \mathrm{R}_{1}\right) /\left(\mathrm{t}_{2}-\mathrm{t}_{1}\right) \\
& \text { RGR-Total }=\text { RGR-L }+ \text { RGR-S }+ \text { RGR-R }
\end{aligned}
$$

The variables are represented by $\mathrm{L}_{1}=$ initial leaf mass (g), $\mathrm{L}_{2}=$ final leaf mass $(\mathrm{g}), \mathrm{S}_{1}=$ initial stem mass $(\mathrm{g}), \mathrm{S}_{2}$ = final stem mass $(\mathrm{g}), \mathrm{R}_{1}=$ initial root mass $(\mathrm{g}), \mathrm{R}_{2}=$ final root mass $(\mathrm{g}), \mathrm{t}_{1}=$ initial time (months) and $\mathrm{t}_{2}=$ final time (months).

Gas exchange measurements: Photosynthesis $\left(A_{\max }\right)$, dark respiration $\left(R_{d}\right)$, stomatic conductance $\left(g_{s}\right)$ and transpiration $(E)$ were determined with a portable, open system, infrared gas analyser (IRGA), model LI-COR 6400. The measurements were made between 20 and 30 days after the installation of the experiment. In addition, the measurements were made between 9:00 and 11:00 a.m. on completely expanded leaves located in the middle-third of the plant. Five replicates of each measurement were obtained. Light curves were made for a photon flux density $(P P F D)$ between 0 and $2000 \mu \mathrm{mol} \cdot \mathrm{m}^{-2} \cdot \mathrm{s}^{-1}$ and the leaf chamber equipment was adjusted to analyse concentrations of $\mathrm{CO}_{2}$ and water vapour at $385 \pm 10 \mu \mathrm{mol} \cdot \mathrm{mol}^{-1}$ and $21 \pm 1 \mathrm{mmol} \cdot \mathrm{mol}^{-1}$, respectively, with a temperature of $31 \pm 1^{\circ} \mathrm{C}$. For data analysis, the model of the non-rectangular hyperbole equation was used to adjust the photosynthetic response to light curve for each plant (Lieth and Reynolds, 1987):

$\mathrm{A}=\left\{\left[\left(\phi_{\mathrm{a}} \mathrm{I}+A^{\prime}{ }_{\text {max }}+R_{d}\right)-\left(\left(\phi_{\mathrm{a}} \mathrm{I}+A^{\prime}{ }_{\text {max }}+R_{d}\right)^{2}-4 \phi_{\mathrm{a}} \mathrm{I} \Theta\left(A^{\prime}{ }_{\text {max }}+\right.\right.\right.\right.$ $\left.\left.\left.\left.R_{d}\right)\right)^{0.5}\right] / 2 \Theta\right\}-R_{d}(5)$

where A represents the rate of net photosynthesis [ $\mu \mathrm{mol}$ $\left.\mathrm{CO}_{2} \cdot \mathrm{m}^{-2} \cdot \mathrm{s}^{-1}\right], A_{\text {max }}^{\prime}$ represents the rate of maximum photosynthesis under conditions of saturated light, $\phi_{\mathrm{a}}$ represents the apparent quantum yield $\left[\mathrm{mol} \mathrm{CO}_{2} \cdot \mathrm{mol}^{-1}\right.$ (quanta)], I represents the light intensity, and $\Theta$ represents the regression curve factor. In order to avoid a correlation between $\phi_{\mathrm{a}}$ and $\Theta$, during the curve adjustment, $\phi_{\mathrm{a}}$ was first estimated using a linear regression from the initial portion of the curve between 0 and $100 \mu \mathrm{mol} \cdot \mathrm{m}^{-2} \cdot \mathrm{s}^{-1}$, using $\phi_{\mathrm{a}}$ as the angular coefficient of the linear regression. The values of $A^{\prime}{ }_{\text {max }}$ and $\Theta$ were estimated with a non-rectangular hyperbole regression described by Lieth and Reynolds (1987) and using 
the software Statistics 6.0 Windows version (StatSoft, Inc., Tulsa, USA). The value of $A_{\max }$ was estimated from the curve adjustment, corresponding to the value of $A$ at the $P P F D$ point equal to $2000 \mu \mathrm{mol} \cdot \mathrm{m}^{-2} \cdot \mathrm{s}^{-1}$. The light compensation point $\left(\mathrm{I}_{\mathrm{c}}\right.$; $P P F D$ in which $\mathrm{A}=0$ ) was calculated by the formula $\mathrm{I}_{\mathrm{c}}=R_{d} /$ $\phi_{\mathrm{a}}$ and the light saturation $\left(\mathrm{I}_{\mathrm{s}} ; P P F D\right.$ in which $\left.\mathrm{A}=90 \% A_{\max }\right)$ was estimated by the equation (5).

The water-use efficiency (WUE) and the intrinsic wateruse efficiency (WIUE) were calculated using the following equations $\left[\mathrm{mmol} \quad \mathrm{CO}_{2} \cdot \mathrm{mol}^{-1}\left(\mathrm{H}_{2} \mathrm{O}\right)\right]=$ photosynthesis (A) / transpiration and IWUE [ $\left.\mu \mathrm{mol} \mathrm{CO} \mathrm{CO}_{2} \cdot \mathrm{mol}^{-1} \mathrm{H}_{2} \mathrm{O}\right]=$ photosynthesis / stomatal conductance.

Pigment analysis: After the gas exchange readings, the marked leaves were collected for pigment analysis. These were performed with $0.1 \mathrm{~g}$ of fresh material ground in 10 $\mathrm{mL}$ of $80 \%$ acetone and magnesium carbonate $\left(\mathrm{MgCO}_{3}\right)$ and immediately afterwards $10 \mathrm{~mL}$ of $100 \%$ acetone were added. The suspension was filtered and absorbance was read at 663 nm (chlorophyll $a-\mathrm{Chl} a$ ), $645 \mathrm{~nm}$ (chlorophyll $b-\mathrm{Chl} b$ ) and $480 \mathrm{~nm}$ (carotenoids $-\mathrm{C}_{\mathrm{x}+\mathrm{c}}$ ) (Hendry and Price, 1993).

Chlorophyll a fluorescence measurements: The chlorophyll fluorescence was determined using a portable fluorometer (Plant Efficiency Analyser-PEA, MK2-9600-Hansatech, Norfolk, UK) between 9:00 and 11:00 am on leaves located in the middle-third of the plant. For each treatment, five leaves were selected (subsamples) as replicates. The leaves of $A$. rosaeodora were subjected to a period of dark adaptation for $15 \mathrm{~min}$. Leaves were then exposed to a pulse of high intensity saturated light $\left(2250 \mu \mathrm{mol} \mathrm{m} \mathrm{m}^{-2} \mathrm{~s}^{-1}\right)$ and the fluorescence measurements were taken immediately afterwards (Gonçalves et al., 2001). From the induction of fluorescence of fast kinetics, the initial fluorescence $\left(F_{o}\right)$, maximum fluorescence $\left(\mathrm{F}_{\mathrm{m}}\right)$, variable fluorescence $\left(F_{v}=F_{m}-F_{o}\right)$ and photochemical efficiency of PSII $\left(F_{v} / F_{m}\right)$ were obtained. The measurements were made in three periods of evaluation: 2 , 30 and 60 days after the installation of the experiment.

Experimental design and statistical analysis: The experimental design was completely randomised with 4 treatments and 5 replicates. The data was subjected to variance analysis and the means were compared by the Tukey test at $5 \%$ probability. In addition, regression analyses were applied for the light curve adjustments. The software Statistics (version 6.0) and SAEG/UFV (version 5.0) were used for statistical analysis.

\section{RESULTS AND DISCUSSION}

Young plants of $A$. rosaeodora subjected to the 500 to $800 \mu \mathrm{mol} . \mathrm{m}^{-2} \cdot \mathrm{s}^{-1}$ (treatment $\mathrm{T}_{2}$ ) exhibited higher values for the relative growth rates of leaf (RGR-L), stem (RGR-S), root (RGR-R) and total mass (RGR-total) when compared with high light intensity treatment $\mathrm{T}_{4}\left(1300\right.$ to $1800 \mu \mathrm{mol} \cdot \mathrm{m}^{-2} \cdot \mathrm{s}^{-1}$, Figure 1). For treatment $\mathrm{T}_{4}$, there was a loss of leaf mass of the plants $\left(-0.005 \mathrm{~g} \cdot \mathrm{g}^{-1} \cdot \mathrm{m}^{-1}\right)$. In addition, plants in $\mathrm{T}_{2}$ presented values of RGR-S, RGR-R and RGR-total approximately 50 , 225 and $67 \%$ greater than the values found for treatment $\mathrm{T}_{1}$ and 125,550 and $650 \%$ greater than the values found for treatment $\mathrm{T}_{4}$, respectively (figure 1). The response of most trees to changes in light intensity varies depending on the species (Thompson et al., 1992). Some studies revealed that plants growing under shade exhibit a lower biomass production when compared with plants growing under higher irradiance (Huante and Rinc, 1998; Nakazono et al., 2001). Nevertheless, when some species are subjected to conditions of high light intensity, they may show a decrease in the accumulation of biomass due to photoinhibition (Stancato et al., 2002). In the case of $A$. rosaeodora, our results indicate that conditions corresponding to treatment $\mathrm{T}_{2}$ (500 to 800 umol. $\left.\mathrm{m}^{-2} \cdot \mathrm{s}^{-1}\right)$ improved performance of the plants. This can be seen by the higher accumulation of biomass in the roots and shoots of the plant (figure 1).

The maximal photosynthetic rates $\left(A_{\max }\right)$ ranged from 2.27 to $6.92 \mu \mathrm{mol} \mathrm{CO}_{2} \cdot \mathrm{m}^{-2} \cdot \mathrm{s}^{-1}$ among treatments, with a range of $205 \%$ from the lowest to the highest values (table 1). The plants in $T_{3}$ (700 to $1000 \mu \mathrm{mol} \cdot \mathrm{m}^{-2} \cdot \mathrm{s}^{-1}$ ) showed the greatest rate of photosynthesis while the plants in $\mathrm{T}_{4}$ (1300 to $1800 \mu \mathrm{mol} . \mathrm{m}^{-2} \cdot \mathrm{s}^{-1}$ ) exhibited the lowest values of $A_{\max }$ (table 1 and figure 2). It was also observed that the highest value of $A_{\max }$ found for $A$. rosaeodora ranges among values found for other tropical tree species that varied between 2.2 and 18.2 $\mu \mathrm{mol} . \mathrm{m}^{-2} . \mathrm{s}^{-1}$ (Zotz and Winter, 1994; Barker et al., 1997; Loik and Holl, 2001; Marenco et al., 2001; Santos and Buckeridge, 2004). Although these responses can be determined by the age of the plant, time of year and ecological function (pioneer, intermediate or climax), light intensity has been considered one of the most important factors that affect the functioning of the photosynthetic mechanism and the adaptation to the light conditions in the environment (Pessarakli, 1997). For A. rosaeodora, the relatively low photosynthetic efficiency exhibited by treatment $T_{4}$ resulted in lower investment in biomass, which may be associated with stress due to high light intensity. Dark respiration $\left(R_{d}\right)$ ranged from 0.61 to $1.16 \mu \mathrm{mol} \mathrm{CO} \mathrm{CO}_{2} \cdot \mathrm{m}^{-2} \cdot \mathrm{s}^{-1}$, in which the values increased with 
increasing light intensity (table 1). It is also important to point out that $R_{d}$ is of great use for the production of the energy necessary for plant growth according to Lambers et al. (1998). The rates of $R_{d}$ are influenced by environmental factors, exhibiting higher rates under conditions of high irradiance. With regard to the apparent quantum yield $\left(\phi_{\mathrm{a}}\right)$, we observed that treatment $\mathrm{T}_{2}$ had the highest value (0.037 mol CO $2 \cdot \mathrm{mol}^{-1}$ photons) whereas $\mathrm{T}_{3}$ and $\mathrm{T}_{1}$ were intermediate and $\mathrm{T}_{4}(0.021)$ showed the lowest value (table 1). The low value found for $T_{4}$ could be associated with an excess of light. Marenco et al. (2001), in a study of the species Swietenia macrophylla, found the highest values for $\phi_{\mathrm{a}}$ in environments with direct sunlight exposure. This finding may be related to the influence of different environmental conditions and the intrinsic characteristics of each species, since some species may possess either greater or lower photosynthetic plasticity. For the convexity factor $(\Theta)$, the values ranged from 0.92 to 0.97 (table 1). Considering that the convexity factor is related to light saturation in the chloroplasts, this variable could change in the presence of high irradiance. The values of $\Theta$ decreased in response to the increase in light in treatments $T_{1}$ to $T_{3}$, indicating more efficient response to the use of light energy at intermediate levels of irradiance. However, a high value for $\Theta$ in the treatment exposed to direct sunlight $\left(T_{4}\right)$ could reflect the degree of photoinhibition resulting from high light intensity (Werner et al., 2001).

Plants under conditions that potentially lead to photoinhibition tend to exhibit a decrease in photosynthesis and generally result in an increase in $\Theta$ as observed in the plants subjected to treatment $\mathrm{T}_{4}$. With regard to the compensation irradiance $\left(I_{c}\right)$, the values ranged from 19 to 54 umol. $\mathrm{m}^{-2} . \mathrm{s}^{-1}$ and increased with increasing light intensity. The highest value of $\mathrm{I}_{\mathrm{c}}$ found for $A$. rosaeodora in the treatment exposed to direct sunlight $\left(\mathrm{T}_{4}\right)$ was a result of the high value of $R_{d}$ and the low value of $\phi_{\mathrm{a}}$. Light saturation $\left(I_{s}\right)$ for $A$. rosaeodora showed a positive response to the increasing light intensities for the first three treatments $\left(\mathrm{T}_{1}\right.$, $\mathrm{T}_{2}$ and $\mathrm{T}_{3}$ ), but a reduced response when subjected to direct sunlight, which may be indicative of photosynthetic damage resulting from excess light (Werner et al., 2001).

It is well known that light saturation varies in function of light intensity and the species being examined. In $A$. rosaeodora, it was observed that $I_{s}$ as well as $I_{c}$ increase with increasing light intensities in the first three treatments $\left(\mathrm{T}_{1}, \mathrm{~T}_{2}\right.$ and $\mathrm{T}_{3}$ ). This was also observed in treatment $\mathrm{T}_{4}$, where there
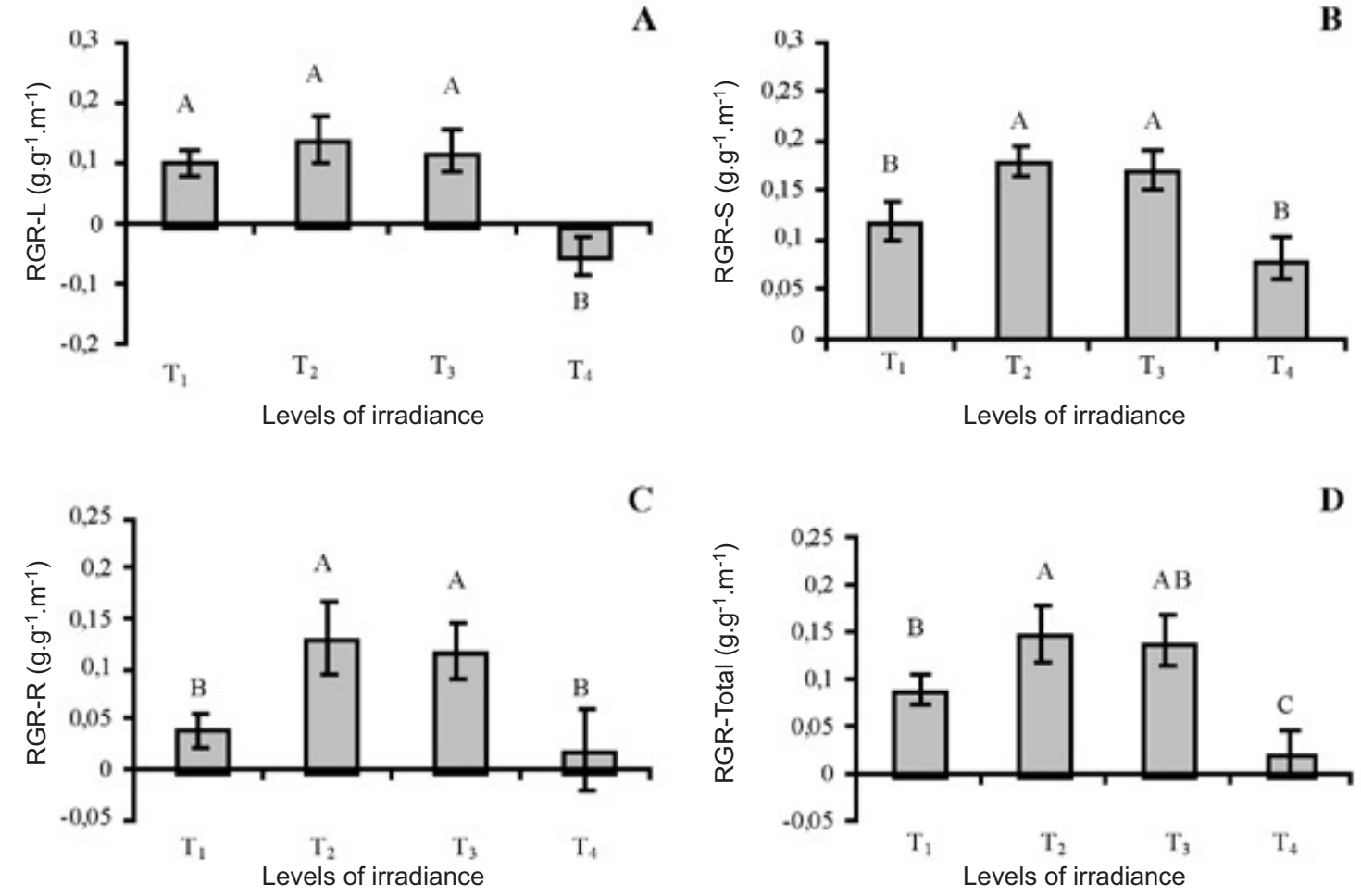

Figure 1. Relative growth rate of young plants of $A$. rosaeodora under different irradiance levels $\left(\mathrm{T}_{1}=10\right.$ a $250, \mathrm{~T}_{2}=500 \mathrm{a} 800, \mathrm{~T}_{3}=700 \mathrm{a}$ $\left.1000 \mathrm{e} \mathrm{T}_{4}=1300 \mathrm{a} 1800 \mu \mathrm{mol} . \mathrm{m}^{-2} \cdot \mathrm{s}^{-1}\right)$. RGR-L = relative growth rate of leaf mass, RGR-S = relative growth rate of stem mass, RGR-R $=$ Relative growth rate of roots mass and RGR-Total $=$ Relative growth rate of total plant mass. Mean values \pm S.D. followed by same letters for treatments are not different at $P \leq 0.05$ using the Tukey test. 
Table 1. Effect of increasing light intensities on the photosynthetic characteristics of young plants of Aniba rosaeodora.

\begin{tabular}{ccccccc}
\hline Light Intensity & $\begin{array}{c}\text { Maximal } \\
\text { photosynthesis } \\
\left(A_{\max }\right)\end{array}$ & $\begin{array}{c}\text { Dark } \\
\text { respiration }\left(R_{d}\right)\end{array}$ & $\begin{array}{c}\text { Quantum yield } \\
\left(\phi_{\mathrm{a}}\right)\end{array}$ & $\begin{array}{c}\text { Convexity factor } \\
(\theta)\end{array}$ & $\begin{array}{c}\text { Compensation } \\
\text { point } \\
\left(I_{c}\right)\end{array}$ & $\begin{array}{c}\text { Light saturation } \\
\left(I_{s}\right)\end{array}$ \\
\cline { 2 - 7 }$\left(\mu \mathrm{mol} \cdot \mathrm{m}^{-2} \cdot \mathrm{s}^{-1}\right)$ & $\mu \mathrm{mol} \cdot \mathrm{m}^{-2} \cdot \mathrm{s}^{-1}$ & $\mu \mathrm{mol}^{-2} \cdot \mathrm{s}^{-1}$ & $\mathrm{~mol}^{-1} \mathrm{~mol}^{-1}$ & - & $\mu \mathrm{mol}^{-2} \cdot \mathrm{s}^{-1}$ & $\mu \mathrm{mol}^{-2} \cdot \mathrm{m}^{-2} \cdot \mathrm{s}^{-1}$ \\
\hline $\mathrm{T}_{1}=10 \mathrm{a} 250$ & $5.57 \pm 0.03 \mathrm{c}$ & $0.61 \pm 0.19 \mathrm{~b}$ & $0.033 \pm 0.002 \mathrm{~b}$ & $0.97 \pm 0.01 \mathrm{a}$ & $19 \pm 6 \mathrm{~d}$ & $230 \pm 27 \mathrm{c}$ \\
$\mathrm{T}_{2}=500 \mathrm{a} 800$ & $6.32 \pm 0.01 \mathrm{~b}$ & $1.05 \pm 0.05 \mathrm{a}$ & $0.037 \pm 0.000 \mathrm{a}$ & $0.93 \pm 0.00 \mathrm{~b}$ & $28 \pm 1 \mathrm{c}$ & $330 \pm 14 \mathrm{~b}$ \\
$\mathrm{~T}_{3}=700 \mathrm{a} 1000$ & $6.92 \pm 0.03 \mathrm{a}$ & $1.11 \pm 0.07 \mathrm{a}$ & $0.031 \pm 0.001 \mathrm{~b}$ & $0.92 \pm 0.00 \mathrm{~b}$ & $35 \pm 2 \mathrm{~b}$ & $440 \pm 12, \mathrm{a}$ \\
$\mathrm{T}_{4}=1300 \mathrm{a} 1800$ & $2.27 \pm 0.01 \mathrm{~d}$ & $1.16 \pm 0.07 \mathrm{a}$ & $0.021 \pm 0.001 \mathrm{c}$ & $0.97 \pm 0.00 \mathrm{a}$ & $54 \pm 1 \mathrm{a}$ & $218 \pm 20 \mathrm{c}$ \\
\hline
\end{tabular}

Mean \pm S.D. followed by same letters for treatments are not different at $P \leq 0.05$ using the Tukey test.

was a decrease in $I_{s}$ (table 1). These results suggest that under high light intensity, damage caused by photoinhibition of the photosynthetic apparatus may have inhibited the ability of the system to cope with an excess of electrons in the photochemical processes. This also resulted in high values of $\Theta$. Different values of light saturation have been found for many species in different environmental conditions (Chow et al., 1998; Krause et al., 1999; Marenco et al., 2001; Aidar et al., 2002; Santos and Buckeridge, 2004). Additionally, under some microenvironmental conditions the photosynthetically active radiation varies both spatially and temporally, thus inducing plants to develop mechanisms of acclimation and greater plasticity to face different conditions of light (Zhang et al., 2002). This appears to be the case in certain regions of the Amazon forest. Data collected in one of the towers installed near Manaus (ZF-2) shows that the maximal light intensity near the ground of the forest, can reach rather high values such as $1000 \mu \mathrm{mol} . \mathrm{m}^{-2} \cdot \mathrm{s}^{-1}$ for several consecutive days. This period can be preceded and subsequently followed by short periods of lower light intensities ranging from 200 to $300 \mu \mathrm{mol} \cdot \mathrm{m}^{-2} \cdot \mathrm{s}^{-1}$. Thus, plants must be able to respond to

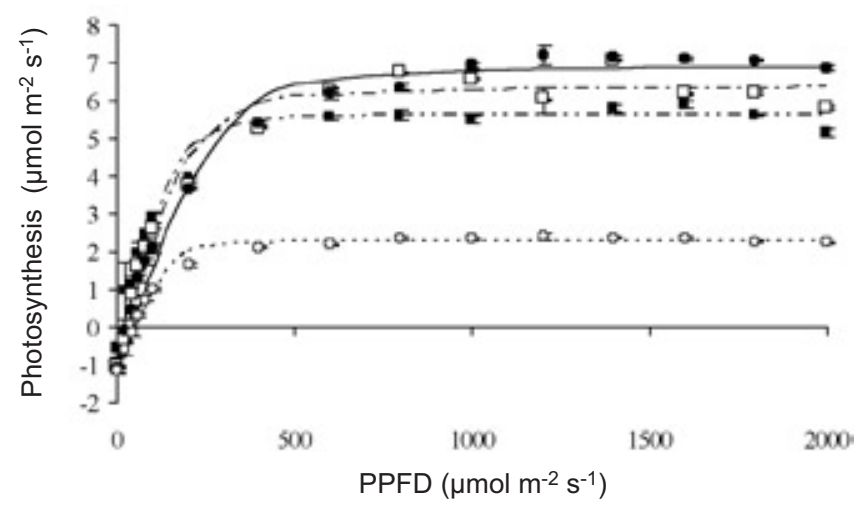

Figure 2. Effect of the light intensity $(P P D F)$ on the rate of net photosynthesis in the leaves of young plants of $A$. rosaeodora $\left[\mathrm{T}_{1}=10\right.$ a $250 \mu \mathrm{mol} \cdot \mathrm{m}^{-2} \cdot \mathrm{s}^{-1}(\boldsymbol{\square}), \mathrm{T}_{2}=500$ a $800 \mu \mathrm{mol} \cdot \mathrm{m}^{-2} \cdot \mathrm{s}^{-1}$ (口), $\mathrm{T}_{3}=700 \mathrm{a} 1000 \mu \mathrm{mol} \cdot \mathrm{m}^{-2} \cdot \mathrm{s}^{-1}(\bullet)$ and $\mathrm{T}_{4}=1300$ a 1800 $\left.\mu \mathrm{mol} \cdot \mathrm{m}^{-2} \cdot \mathrm{s}^{-1}(\mathrm{O})\right]$. light in a rather flexible manner so that they can survive in the understorey of the rain forest. This probably explains the observed changes in the saturation points when all variables associated with photosynthesis change (table 1 and figure 2).

Regarding water use efficiency (WUE), it was observed that when young plants of $A$. rosaeodora grew under direct sunlight $\left(\mathrm{T}_{4}\right)$ a lower transpiration rate $(E)$ was observed (table 2). This indicates that this species presents a relatively low WUE when subjected to high light intensity. Stomatic conductance $\left(g_{s}\right)$, ranged from 116 to $174 \mathrm{mmol} \cdot \mathrm{m}^{-2} \cdot \mathrm{s}^{-1}$. These values are between those found for other tropical species, which vary between 97 and $1250 \mathrm{mmol} \cdot \mathrm{m}^{-2} \cdot \mathrm{s}^{-}$ 1 (Jarvis and McNaughton, 1986; Carswell et al., 2000; Loik and Holl, 2001; Marenco et al., 2001). Therefore, the values of $g_{s}$ in $A$. rosaeodora are low and might be related to ecophysiological features of the species in respect to its ecological function (mid - successional).

Water use efficiency ranged from 1.08 to $2.79 \mathrm{mmol}$ $\mathrm{CO}_{2} \cdot \mathrm{mol}^{-1} \mathrm{H}_{2} \mathrm{O}$, and a higher value was observed in treatment $\mathrm{T}_{3}$ than in treatment $\mathrm{T}_{4}$ (table 2). For the intrinsic water use efficiency (IWUE), the highest value (45 $\mathrm{mmol}$ $\mathrm{CO}_{2} \cdot \mathrm{mol}^{-1} \mathrm{H}_{2} \mathrm{O}$ ) was also observed in treatment $\mathrm{T}_{3}$ (table 2). These results indicate that $A$. rosaeodora exhibit limitations in relation to the use of water as a result of the partial opening of the stomata, with a decrease in the values of $I W U E$ due to the increase in light intensity.

Pigment concentrations ( $\mathrm{Chl} a, \mathrm{Chl} b, \mathrm{Chl}{ }_{\text {total }}$ and $\mathrm{C}_{\mathrm{x}+\mathrm{c}}$ ) for the treatment in the shade $\left(\mathrm{T}_{1}\right)$ were respectively 176 , 159, 174 and $83 \%$ greater than the concentrations found for the treatment in direct sunlight $\left(\mathrm{T}_{4}\right)$ (table 3 ). It was also observed that the levels chlorophylls $a$ and $b$ tended to decrease with the increase in light intensity (table 3). Similar results were found by Nakazono et al. (2001). The synthesis and degradation of the photosynthetic pigments are normally associated with the photosynthetic efficiency of the plants as well as their growth and adaptability to different 
environments (Engel and Poggiani, 1991). The chlorophylls are usually synthesized and photo-oxidised in the presence of light (Kramer and Kozlowski, 1979). However, under conditions of high light intensity, the degradation of the chlorophyll molecules might be more intense and equilibrium occurs at lower concentrations.

It was observed that the chlorophyll concentrations in shaded leaves tend to be higher when compared with leaves exposed to direct sunlight (Boardman, 1977). Under field conditions in Central Amazonia, adult plants of Swietenia macrophylla and Dipteryx odorata exhibited similar behaviour, in which the concentrations of pigments in leaves of plants under shade treatment were greater than the concentration of those exposed to direct sunlight (Gonçalves et al., 2001).

Regarding the ratio between chlorophylls (Chl $a / b)$, no differences amongst the species studied were found. According to Whatley and Whatley (1982), a greater proportion of chlorophyll $b$ in leaves of shaded plants is an important characteristic because it allows for the capture of energy at different portion of the electromagnetic spectrum. Krause et al. (2001) observed differential responses in the values of $\mathrm{Chl} a / b$ for plants of Dryepetes standleyi growing in small, medium, and wide gaps in the forest. D. standleyi exhibited the lower levels of chlorophyll when growing in medium gaps whereas Quararibea asterolepsis exhibited the lowest levels in wide gaps. The behaviour of $Q$. asterolepsis is similar to that shown here for $A$. rosaeodora.

In $A$. resaeodora the ratios total chlorophyll /carotenoids $\left(\mathrm{Chl}_{\text {total }} / \mathrm{C}_{\mathrm{x}+\mathrm{c}}\right)$ ranged from 2.0 to 3.0 among treatments. Plants subjected to treatment $T_{1}$ had the highest value and the plants subjected to treatment $T_{4}$ had the lowest. The lowest value for $\mathrm{Ch}_{\text {total }} / \mathrm{C}_{\mathrm{x}+\mathrm{c}}$ in treatment $\mathrm{T}_{4}$ may be considered as a photoprotective mechanism against high irradiance. These results suggest that $A$. rosaeodora, usually classified as a mid-successional species, showed considerable plasticity for capture and usage of light, particularly at young stages, by increasing the concentration of pigments under low light conditions and decreasing $\mathrm{Chl}_{\text {total }} / \mathrm{C}_{\mathrm{x}+\mathrm{c}}$ at high irradiance to minimize the damage caused by photoinhibition.

Regarding chlorophyll $a$ fluorescence, it was observed that the initial fluorescence $\left(F_{o}\right)$ did not vary significantly among the treatments with the exception of the treatment in direct sunlight, which after 30 days presented a decrease in the initial fluorescence followed by an increase after 60 days (figure 3A). Similar behaviour was observed over the different periods, in which the treatments $\mathrm{T}_{2}, \mathrm{~T}_{3}$ and $\mathrm{T}_{4}$ experienced a decrease in both $F_{v}$ and $F_{m}$ after 30 days, before returning to their normal values (figures $3 \mathrm{~B}$ and $3 \mathrm{C}$, respectively).

For the photochemical efficiency of PS II $\left(F_{v} / F_{m}=\right.$ $\left.\left(F_{m}-F_{o}\right) / F_{m}\right)$, the shaded treatment induced stability in its

Table 2. Effect of increasing light intensities on gas exchange in young plants of Aniba rosaeodora.

\begin{tabular}{ccccc}
\hline $\begin{array}{c}\text { Light intensities } \\
\left(\mu \mathrm{mol} \cdot \mathrm{m}^{-2} \cdot \mathrm{s}^{-1}\right)\end{array}$ & $\begin{array}{c}\text { Transpiration } \\
(E)\end{array}$ & $\begin{array}{c}\text { Stomatic conductance } \\
\left(g_{s}\right)\end{array}$ & $\begin{array}{c}\text { Water use efficiency } \\
(W U E)\end{array}$ & $\begin{array}{c}\text { Intrinsec water use efficiency } \\
(I W U E)\end{array}$ \\
\cline { 2 - 5 } & $M m o l \cdot \mathrm{m}^{-2} \cdot \mathrm{s}^{-1}$ & $\mathrm{mmol}^{-2} \mathrm{~m}^{-1}$ & $\mathrm{mmol}^{-1} \mathrm{~mol}^{-1}$ & $\mu \mathrm{mol}^{-1} \mathrm{~mol}^{-1}$ \\
$\mathrm{~T}_{1}=10 \mathrm{a} 250$ & $2.03 \pm 0.01 \mathrm{~b}$ & $116 \pm 1 \mathrm{~d}$ & $2.54 \pm 0.05 \mathrm{~b}$ & $44.55 \pm 1.05 \mathrm{a}$ \\
$\mathrm{T}_{2}=500 \mathrm{a} 800$ & $2.45 \pm 0.00 \mathrm{a}$ & $174 \pm 1 \mathrm{a}$ & $2.35 \pm 0.01 \mathrm{c}$ & $33.33 \pm 0.17 \mathrm{~b}$ \\
$\mathrm{~T}_{3}=700 \mathrm{a} 1000$ & $2.45 \pm 0.00 \mathrm{a}$ & $152 \pm 1 \mathrm{~b}$ & $2.79 \pm 0.03 \mathrm{a}$ & $45.11 \pm 0.69 \mathrm{a}$ \\
$\mathrm{T}_{4}=1300 \mathrm{a} 1800$ & $2.06 \pm 0.01 \mathrm{~b}$ & $138 \pm 1 \mathrm{c}$ & $1.08 \pm 0.01 \mathrm{~d}$ & $16.15 \pm 0.22 \mathrm{c}$ \\
\hline
\end{tabular}

Mean \pm S.D. followed by same letters for treatments are not different at $P \leq 0.05$ using the Tukey test.

Table 3. Effect of increasing light intensities on the concentration of leaf pigments ( $\mu \mathrm{mol} \mathrm{m} \mathrm{m}^{-2}$ ) and ratios between chlorophylls $a / b(\mathrm{Chl} a / b)$ and chlorophyll/carotenoids $\left(\mathrm{Chl}_{\text {tot }} / \mathrm{C}_{\mathrm{x}+\mathrm{c}}\right)$ in young plants of Aniba rosaeodora.

\begin{tabular}{|c|c|c|c|c|c|c|}
\hline \multirow{2}{*}{$\begin{array}{l}\text { Light intensity } \\
\left(\mu \mathrm{mol} \cdot \mathrm{m}^{-2} \cdot \mathrm{s}^{-1}\right)\end{array}$} & Chlorophyll $a$ & Chlorophyll $b$ & Total chlorophyll & Carotenoids & \multirow[t]{2}{*}{ Chl $a / b$} & \multirow{2}{*}{$\mathrm{Chl}_{\mathrm{tot}} / \mathrm{C}_{\mathrm{x}+\mathrm{c}}$} \\
\hline & \multicolumn{4}{|c|}{$\mu \mathrm{mol} . \mathrm{m}^{-2}$} & & \\
\hline $\mathrm{T}_{1}=10 \mathrm{a} 250$ & $387 \pm 24 \mathrm{a}$ & $163 \pm 24 \mathrm{a}$ & $557 \pm 51 \mathrm{a}$ & $183 \pm 5 \mathrm{a}$ & $2.4 \pm 0.2 \mathrm{a}$ & $3.0 \pm 0.2 \mathrm{a}$ \\
\hline $\mathrm{T}_{2}=500 \mathrm{a} 800$ & $203 \pm 23 b$ & $83 \pm 5 b$ & $293 \pm 20 b$ & $110 \pm 1 b$ & $2.4 \pm 0.4 \mathrm{a}$ & $2.7 \pm 0.2 \mathrm{ab}$ \\
\hline $\mathrm{T}_{3}=700 \mathrm{a} 1000$ & $193 \pm 57 b$ & $103 \pm 42 \mathrm{ab}$ & $303 \pm 99 b$ & $127 \pm 32 \mathrm{ab}$ & $1.9 \pm 0.3 \mathrm{a}$ & $2.4 \pm 0.3 \mathrm{ab}$ \\
\hline $\mathrm{T}_{4}=1300 \mathrm{a} 1800$ & $140 \pm 19 b$ & $63 \pm 10 b$ & $203 \pm 27 b$ & $100 \pm 24 \mathrm{~b}$ & $2.2 \pm 0.3 \mathrm{a}$ & $2.0 \pm 0.3 \mathrm{~b}$ \\
\hline
\end{tabular}

Mean \pm S.D. followed by same letters for treatments are not different at $P \leq 0.05$ using the Tukey test. 
behaviour over the experimental period. In the treatments $\mathrm{T}_{2}$ and $\mathrm{T}_{3}$, the plants showed a decrease in $F_{v} / F_{m}$ after 30 days, and subsequently returned to normal behaviour after 60 days. In the treatment where plants were exposed to direct sunlight $\left(\mathrm{T}_{4}\right)$, strong photoinhibition was observed (figure 3D). It is possible that the increase in temperature might have contributed to photoinhibition (Kitao et al., 2000). On the other hand, Gonçalves et al. (2001) observed for $S$. macrophylla (mid-successional species) a decrease of $6 \%$ in $F_{v} / F_{m}$ whereas for D. odorata (late-successional) no differences were observed between plants grown under high and low light intensities. It is possible that the small difference observed for the former species could be related to mechanisms of adaptation of mid-successional species to higher light intensities. Such a behaviour was observed for $A$. rosaeodora, whose $F_{v} / F_{m}$ ratio decreased along the 60 days of the experiment.

Zhang et al. (2002) observed significant decrease in $F_{v} /$ $F_{m}$ in saplings grown under low light density and suddenly exposed to high light intensity, indicating that photosystem II was partially inactivated. Krause et al. (2001) observed that during the periods of direct sun exposure, all the plants exhibited significant photoinhibition of PS II as revealed by a decrease in $F_{v} / F_{m}$.
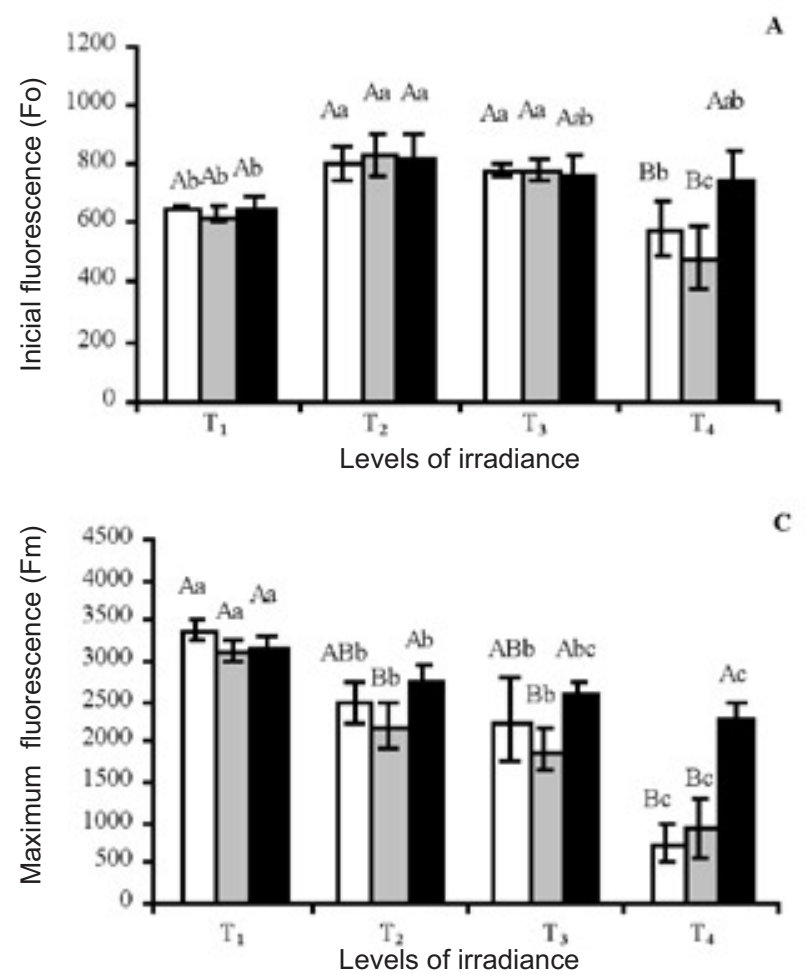

Indeed, exposition to excess of light may cause photoinhibition to a degree that is dependent on the species. This can be measured by the decrease in the parameter of the fluorescence of chlorophyll $a\left(F_{v} / F_{m}\right)$, after exposure to light, representing the maximum photochemical efficiency of photosystem II (Werner et al., 2001). When A. rosaeodora was subjected to treatment $\mathrm{T}_{4}$, we observed a steady decrease in $F_{v} / F_{m}$, which characterised a high level of photoinhibition. The reduction of $F_{v} / F_{m}$ could be the result of an increase in $F_{o}$ or a decrease in $F_{m}$ (Kitao et al., 2000; Oliveira et al., 2002). Nonetheless, after 30 days and 60 days, there was an increase in the values of $F_{v} / F_{m}$, indicating that there had been an effective response to stress involving an acclimation mechanism to high irradiance. Thus, $A$. rosaeodora was able to adjust its photosynthetic apparatus when subjected to different conditions of light during growth. The consequence of photoinhibition seems to be confirmed by the observations of low values of photosynthesis (measured between 20 and 30 days after the installation of experiment) and biomass accumulation found in plants of $A$. rosaeodora subjected to direct sunlight.

The process of acclimation to environments of high irradiance is rather complex, involving the availability of both water and nutrients. In this study, the physiological
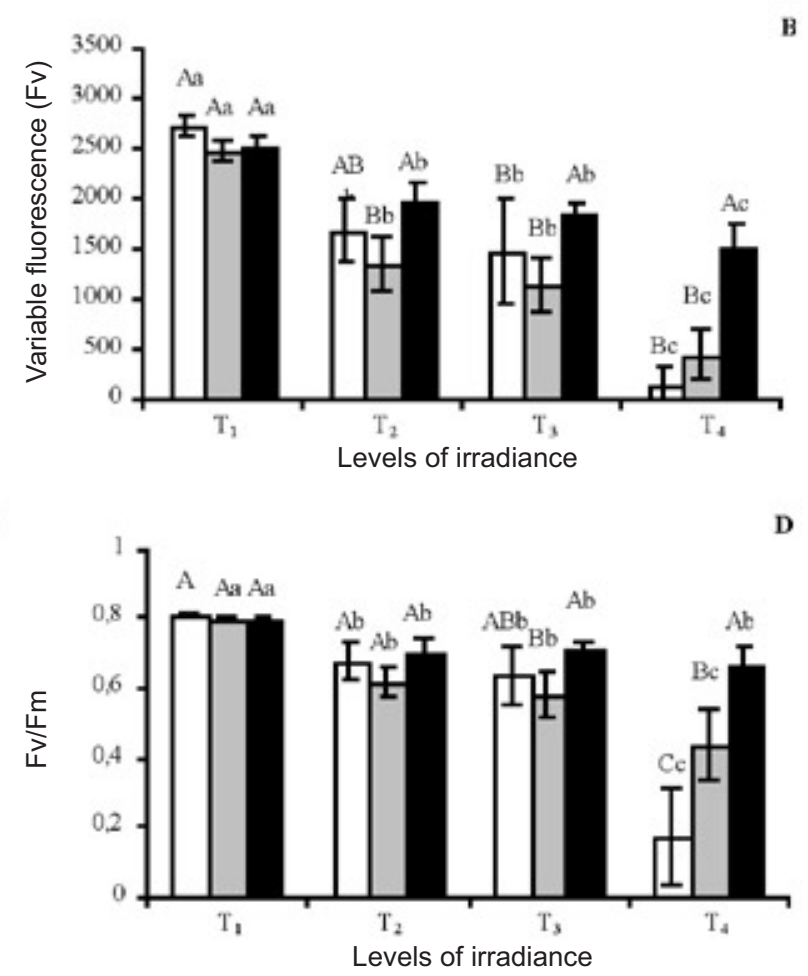

Figura 3. Chlorophyll $a$ fluorescence in young plants of $A$. rosaeodora under different irradiance levels $\left(\mathrm{T}_{1}=10\right.$ a $250, \mathrm{~T}_{2}=500$ a $800, \mathrm{~T}_{3}=$

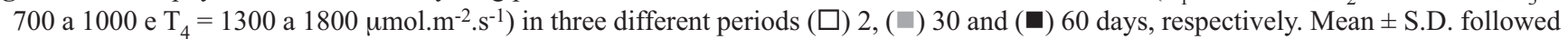
by same capital letters for periods and lower case letter for treatments are not different at $P \leq 0.05$ using the Tukey test. 
behaviour of young plants of $A$. rosaeodora subjected to different light intensities, suggests that its photosynthetic apparatus is more efficient when subjected to environments of medium light intensity, between 500 a $1000 \mu \mathrm{mol} \cdot \mathrm{m}^{-2} \cdot \mathrm{s}^{-1}$. On the other hand, our results show that the photosynthetic activity of this species may be limited when grown in shaded environments or environments with high light intensity, either due to insufficient light intensity in the shaded environment $\left(T_{1}\right)$ or to photoinhibition as a consequence of the excess light in the open environment $\left(\mathrm{T}_{4}\right)$. The better photosynthetic performance of the species resulted in a greater ability to accumulate biomass. Regarding photosynthetic pigments, we observed that $A$. rosaeodora exhibited plasticity in light capture, developing a photoprotective mechanism when subjected to high intensities of irradiance. Furthermore, $A$. rosaeodora exhibited a higher photosynthetic performance and consequently a higher capacity of biomass accumulation under intermediate light intensities (between 500 a 1300 $\mu$ mol photons. $\mathrm{m}^{-2} \cdot \mathrm{s}^{-1}$ ). On the other hand, extremes of light intensity can limit photosynthesis of young plants of $A$. rosaeodora. Thus, these results indicate that intermediate light conditions are the more adequate for this species to reach higher levels of carbon assimilation and biomass accumulation during its early growth phase.

\section{REFERENCES}

Aidar MPM, Martinez CA, Costa AC, Costa PMF, Dietrich SMC, Buckeridge MS (2002) Effect of atmospheric $\mathrm{CO}_{2}$ enrichment on the establishment of young plants of jatobá, Hymenaea courbaril L. (Leguminosae, Caesalpinioideae). Biota Neotropica 2:1-10.

Alencar JC, Fernandes NP (1978) Desenvolvimento de árvores nativas em ensaios de espécies. I. Pau-rosa (Aniba duckei Kostermans). Acta Amazonica 8:523-541.

Baker NR, Farage PK, Stirling CM, Long SP (1994) Photoinhbition of crop photosynthesis in the field at low temperatures. In: Baker NR, Bowyer JR (eds.), Photoinhbition of photosynthesis - from molecular mechanisms to the field, pp. 349-363. Bios Scientific Publishers, Oxford.

Baker MG, Press MC, Brown ND (1997) Photosynthetic characteristics of dipterocarp young plants in three tropical rain forest light environments: a basis for niche partitioning. Oecologia 122:453-463.

Bartley GE, Scolnik PA (1995). Plant carotenoids: Pigments for photoprotection, visual attraction and human health. Plant Cell 7:1027-1038.

Boardman N.K. (1977) Comparative photosynthesis of sun and shade plants. Annu. Rev. Plant. Physiol. 28:355-377.

Bugbee BG (1996) Growth, analysis and yield components. In: Salisbury FB (ed), Units, Symbols, and Terminology for Plant Physiology, pp. 115-119. Oxford University Press, Oxford, UK.
Carswell FE, Meir P, Wandelli EV, Bonates LCM, Kruijt B, Barbosa EM, Nobre AD, Grace J, Jarvis PG (2000) Photosynthetic capacity in a central Amazonian rain Forest. Tree Physiol. 20:179-186.

Chow WS, Qian L, Goodchild DJ, Anderson JM (1988) Photosynthetic aclimation of Alocasia macrorrhiza (L.) G. Don to growth irradiance: structure, function and composition of chloroplasts. Aust. J. Plant Physiol. 15:107-122.

Davanso VM, Souza LA, Medri ME, Pimenta JA, Bianchini E (2002) Photosynthesis, growth and development of Tabebuia avellanedae Lor. Ex Griseb. (Bignoniaceae) in flooded soil. Braz. Archiv. Biol Tech. 45:375-384.

Engel VL, Poggiane F (1991) Estudo da concentração de clorofila nas folhas e seu espectro de absorção de luz em função do sombreamento em mudas de quatro espécies florestais nativas. Braz. J. Plant Physiol. 3:39-45.

Gonçalves JFC, Marenco RA, Vieira G (2001) Concentration of photosynthetic pigments and chlorophyll fluorescence of mahogany and tonka bean under two light environments. Braz. J. Plant Physiol. 13:149-157.

Hendry GAF, Price AH (1993) Stress indicators: chlorophylls and carotenoids. In: Hendry GAF, Grime JP (eds.), Methods in Comparative Plant Ecology, pp. 148-152. Chapman \& Hall, London, UK.

Huante P, Rincón E (1998) Responses to light changes in tropical deciduous woody young plants with contrasting growth rates. Oecologia 113:53-66.

Instituto Nacional de Pesquisas Espaciais - INPE (2004) http: //www.inpe.br/Informações_Eventos/amazonia.htm.

Jarvis PG, McNaughton KG (1986) Stomatal control of transpiration: scaling up from leaf to region. Adv. Ecol. Res. 15:1-49.

Kitao M, Lei TT, Koike T, Tobita H, Maruyama Y, Matsumoto Y, Ang LH (2000) Temperature response and photoinhibition investigated by chlorophyll fluorescence measurements for four distinct species of dipterocarp trees. Physiol. Plant. 109:284-290.

Kramer T, Kozlowski T (1979) Physiology of Woody Plants. Academic Press, New York, USA.

Krause GH, Schmude C, Garden H, Koroleva OY, Winter K (1999) Effects of solar ultraviolet radiation on the potential efficiency of photosystem II in leaves of tropical plants. Plant Physiol. 121:1349-1358.

Krause GH, Koroleva OY, Dalling JW, Winter K (2001). Acclimation of tropical tree young plants to excessive light in simulated tree-fall gaps. Plant Cell Environ. 24:13451352.

Kull O (2002) Acclimation of photosynthesis in canopies: models and limitations. Oecologia 133:267-279.

Lambers H, Chapin III FS, Pons TL (1998) Plant Physiological Ecology. Springer-Verlag, New York, USA.

Lieth JH, Reynolds JF (1987) The non-rectangular hyperbola as a photosynthetic light response model: geometrical interpretation and estimation of the parameter. $\Theta$. Photosynthetica 21:363-366.

Loik ME; Holl KD (2001) Photosynthetic responses of tree seedlings in glass and under shrubs in early-successional tropical old fields, Costa Rica. Oecologia 127:40-50. 
Marenco RA, Gonçalves JFC, Vieira G (2001) Leaf gas exchange and carbohydrates in tropical trees differing in successional status in two light environments in central Amazonia. Tree Physiol. 21:1311-1318.

May PH, Barata LES (2004) Rosewood exploitation in the Brazilian Amazon: options for sustainable production. Econ. Bot. 58:257-265.

Moraes Neto SP, Gonçalves JLM (2001) Efeitos da luminosidade sobre o estado nutricional de mudas de seis espécies arbóreas que ocorrem na mata Atlântica. Rev. Árvore 25:29-38.

Nakazono EM, Costa MC, Futatsuge K, Paulilo MTS (2001). Crescimento inicial de Euterpe edulis Mart. Em diferentes regimes de luz. Rev. Bras. Bot. 24:173-179.

Oliveira JG, Alves PLCA, Magalhães AC (2002) The effect of chilling on the photosynthetic activity in coffee (Coffea arabica L.) young plants. The protective action of chloroplastid pigments. Braz. J. Plant Physiol. 14:95-104.

Pessarakli M (1997) Handbook of Photosynthesis. Marcel Dekker, Arizona, USA.

Rosa LS, SÁ TDA, Ohashi ST, Barros PLC, Silva AJV (1997) Crescimento e sobrevivência de mudas de pau-rosa (Aniba rosaeodora Ducke) oriundas de três procedências, em função de diferentes níveis de sombreamento, em condições de viveiro. Boletim Faculdade de Ciências Agrárias do Pará 28:37-62.

Sampaio PTB, Barbosa AP, Vieira G, Spironello WR, Ferraz IDK, Camargo JLC, Quisen RC (2003) Silvicultura do Pau Rosa. In: Higuchi N, Santos J, Sampaio PTB, Marenco RA, Ferraz J, Sales PC, Saito M, Matsumoto S (Organizers), Projeto Jacarandá Fase II: Pesquisas Florestais na Amazônica Central. INPA, pp. 179-190.
Sands PJ (1995) Modeling canopy production. II. From single-leaf photosynthetic paramenters to daily canopy photosynthesis. Aust. J. Plant Physiol. 22:603-614.

Santos HP, Buckeridge MS (2004) The role of the storage carbon of cotyledons in the establishment of young plants of Hymenaea courbaril L. under different light conditions. Ann. Bot. 94:819-830.

Stancato GC, Mazzafera P, Buckeridge MS (2002) Carbon assimilation and partitioning in epiphyte orchid Cattleya forbesii Lindl. X Laelia tenebrosa Rolfe under extrem levels of irradiance. Rev. Bras. Bot. 25:229-235.

Thompson WA, Huang LK, Kriedemann PE (1992) Photosynthetic response to light and nutrients in sun-tolerant and shade-tolerant rainforest trees. Leaf gas exchange and component processes of photosynthesis. Aust. J. Plant Physiol. 19:19-42.

Whatley JM, Whatley FR (1982) A luz e a Vida das Plantas. EPU-EDUSP, São Paulo, Brasil.

Werff H, Richter HG (1996) Towards an improved classification of Lauraceae. Annals of the Missouri Botanical Garden. 8:419-432. Ann. Missouri Bot. Garden 83:419-432.

Werner C, Ryel RJ, Correia O, Beyschlag W (2001) Effects of photoinhibition on whole-plant carbon gain assessed with a photosynthesis model. Plant Cell Environ. 24:27-40.

Zhang S, Keping M, Lingzhi C (2003) Response of photosynthetic plasticity of Paeonia suffruticosa to changed light environments. Environ. Exp. Bot. 49:121-133.

Zotz G, Winter K (1994) Photosynthesis of a tropical canopy tree, Ceiba pentandra, in a lowland forest in Panama. Tree Physiol. 14:1291-1301. 